\title{
TEACHING PROFESSIONAL DISCOURSE IN A FOREIGN LANGUAGE THROUGH LEXICAL COMMUNICATOR FORMATION
}

\section{Varieshkina N. V.}

\section{INTRODUCTION}

Economic and socio-cultural changes in the modern world have led to the expansion of cooperation and growth of professional contacts in a foreign language environment.

In the context of the Bologna Declaration, the ideology of teaching a future specialist at the university is changing, new tasks of the educational process are being formed, in which the main place is given to professionally oriented education.

Modern structure of higher education content requires updated professional competences of a specialist, which integral part is knowledge of a foreign language and professional communication rules. Instead of focusing exclusively on the acquisition of ready-made knowledge, the content of education should contribute to the formation of general cultural and professional competences, preparation for learning throughout life. That is why quality of higher education should be characterized not only by a great amount of knowledge in the future professional domain, but also by the ability of graduates to communicate in a foreign language with colleagues from other countries. One of the key factors is students' self-study and, consequently, their independent access to educational resources and technologies of self-education. Motivation and interests of students should also be regarded as a key resource for the effectiveness of education. The level of education of a qualified specialist who has a whole range of competences should also enable him/her to carry out effective communication in a foreign language. This implies the need not only to possess foreign language communicative and intercultural competences, but also to be able to act in the circumstances of professional communication in appropriate manner, to have skills to deal with information in a foreign language, to be able to discuss professional problems. Professionally oriented education should be aimed at forming competences in the field of professional activity and motivation for learning throughout life. It ensures a good foundation for professional mobility in future.

The development of various forms and technologies of teaching foreign languages, changes in the socio-cultural aspect of modern life entail a 
change in the requirements that society imposes on higher education in general, and on linguistic education particularly.

Modern linguistics has become a cycle of knowledge, having absorbed various sections of sciences regardless of the specifics of the chosen profession, and all areas have interdisciplinary spheres of interaction, which is necessary for students of humanitarian specialties that serves as important connecting link for the development of teaching professional discourse in a foreign language.

The psychological and pedagogical conditions for creating a foreign language program for students of humanities faculties should be focused on students' personal development through use of modern teaching methods that contribute to increasing motivation to learn a foreign language as a means of professional foreign language communication based on the use of a foreign language professional discourse.

\section{Discourse as language for communication. Specificities of professional discourse in a foreign language}

The problem of the discourse concept interpretation is not completely new, but since the $60 \mathrm{~s}$ of the last century, it has been paid more and more attention. In modern linguistics, the term "discourse" is very often used as close one to the concept "text". The endless search for equivalents such as language, discourse, type of speech, text, type of text, coherent text, text of speech indicates the ambiguous essence of this concept. Since our study is not devoted to the consideration of the entire evolution of the term "discourse", we will consider only the main problems of understanding this concept, which remains at the center of attention of modern scientific discussions.

Discourse analysis is an interdisciplinary field of knowledge, that not only linguists, but sociologists, psychologists, artificial intelligence specialists, ethnographers, semiotic literary scholars, stylists and philosophers, study.

Let us consider some definitions of this widely used and controversial concept.

American linguist Deborah Schiffrin considers different approaches to the definition of the concept of "discourse". The first approach is based on the positions of formally and structurally oriented linguistics. Based on this approach, discourse can be defined as a language that is higher in level than the sentence and the phrase "language above the sentence". "Roughly speaking, it refers to attempts to study the organization of language above the sentence or above the clause, and therefore to study larger linguistic 
units, such as conversational exchanges or written texts." ${ }^{\prime 1}$ D. Schiffrin shows how the nature of discourse is intertwined with the process of communication, though the actual model of communication assumed under specific approaches may differ. She asserts that, although various approaches to discourse may be governed by different assumptions, they are all united by a shared one: the idea of language as interaction.

Deborah Schiffrin approached the study of conversation unveiling the problems of the analyses of everyday real language in context. Her "Discourse Markers" opened a new dimension to the analysis of discourse and communication in academia; she coined a term that soon became used by the university community and, at the same time, discourse analysis became a subfield of study within linguistics that gained place and interest among researchers. Discourse markers - the particles oh, well, now, then, you know, and I mean, and the connectives so, because, and, but and or perform important functions in discourse. Dr. Schiffrin's approach clearly demonstrates that neither the markers, nor the discourse within which they function, can be understood from one point of view alone, but as an integration of structural, semantic, pragmatic, and social factors. "As such, it cannot be restricted to the description of linguistic forms independent of the purposes or functions which those forms are designed to serve in human affairs." So, we may conclude that Dr. Schiffrin's general aim was the study of language in text and context.

Another concept in the understanding of discourse has a functional basis, where discourse is interpreted as the use of language: "the analysis of discourse is, necessarily, the analysis of language in use" and where the functions of discourse are related to the functions of language. ${ }^{3}$

This approach is also close to the ideas of the Prague Linguistic Circle; its representatives believed that linguistic analysis should be approached from a functional point of view. The Prague Linguistic Circle provided linguistics with new theories such as theory of linguistic functions. It brought novelty in interpreting language but failed to offer a complete theory. Vilem Mathesius by the notion of theme understood what is known or obvious in the given situation, and the point from which the speaker starts in the discourse. But his colleague Travnicek did not agree and defined theme as the sentence element that was linked up directly with the object of thought. Karl Buhler contributed greatly to the structural theory of language,

1 Schiffrin D. Approaches to Discourse. Oxford - Cambridge, Mass. : Basil Blackwell, 1994. P. 30.

${ }^{2}$ Schiffrin D. Discourse Markers. Cambridge, Cambridge University Press, 1987. P. 3.

${ }^{3}$ Brown G., Yule G. Discourse Analysis. Cambridge: Cambridge Univ. Press, 1983. P. 1. 
he found that main linguistic functions start from speaker, recepient, process of communication. Linguists of the Prague Circle stressed the function of elements within language. The Prague scholars attached great significance to external factors such as political, social, and geographical ones and stressed the importance of the social function of languages. "Most representatives of the Prague School of linguistics considered that speech was the reality of language. The concept of linguistic function is one of the most important provisions of the concept of the Prague School of Functional Linguistics." ${ }^{\text {It }}$ follows from this that language is a system of means of expression that serves a specific purpose. It should also be noted that this approach is based on a conditional action, an idea of the development, development from a fragment of a text to speech activity.

Discourse markers are elements that appear in initial or terminal position and can be part of contextual theme. But some authors of the Prague School of linguistics consider that elements that we now name discourse markers are situated outside the theme. One of these authors is Jiri Nosek who writes about sentence constituents as textual elements that connect sentences and utterances into a coherent text. According to Mr. Nosek, the sentence parts, or elements, function as a code which is recurrent and that is why their structure is known to native speakers. Although they operate functionally within one sentence, they can reappear and be repeated beyond the sentence. So, the identification of these items' functional roles within discourse is mainly based on practice and their recurrent uses. But we agree with the researcher M. Matei that "even though native speakers are swift in recognizing the function that such an element exercises, not only them can master possible discursive functions of these items. In the process of foreign language learning these patterns of discourse markers are transmitted to learners by means of conversation, written texts, movies, etc. as they are part of linguistic communication competences that foreign language learners aim to acquire" 5 .

Now let us return to a problem posed earlier concerning interpretations of the term discourse. In her next interpretation of discourse Deborah Schiffrin offers the following definition: "discourse is utterances" with utterances considered as "units of language production that are inherently contextualized" ${ }^{6}$. Thus, she successfully finds the way to manage a middle

4 Звегинцев В.А. Тезисы Пражского Лингвистического Кружка. История языкознания XIX-XX веков в очерках и извлечениях. Москва: Просвещение, 1965. Ч. II. C. $123-140$.

${ }^{5}$ Matei M. Discourse markers as Functional Elements. Bulletin of the Transilvania University of Brasov : Philology and Cultural Studies. 2010. Vol. 3 (52). P. 121.

6 Schiffrin D. Approaches to Discourse. Oxford - Cambridge, Mass. : Basil Blackwell, 1994. P. 39. 
course, combining the focus of formalist on linguistic structures with the functionalist's concern for how language is used in context. Dr. Schiffrin shows us that this is a good strategy which opens possibilities of analysis to those interested in the research of discourse, while at the same time encouraging the use of combined formalist and functionalist theories and methods to study discourse-related issues.

The famous researcher of discourse T. van Dijk suggests using the term "discourse" in many meanings. He proves that discourse can be written, oral, verbal and non-verbal, that is, it can be considered as a written or oral speech product of a communicative action that is associated with specific conditions and context.

In other words, van Dijk writes that discourse in the broadest sense can be written, oral, and can have verbal and non-verbal components; the researcher defines discourse in the narrow sense as a written or oral speech verbal product of communicative activity. Further, the author of the famous work adds that discourse is always associated with specific conditions and context. "The primary meaning of the term "discourse" and as it is used, is that of a specific communicative event. Such a communicative event is itself rather complex, and at least involves several social actors, typically in speaker/writer and hearer/reader roles, taking part in a communicative act, in a specific setting (time, place, circumstances) and based on other context features. This communicative act may be written or spoken, and, especially in spoken interaction, usually combines verbal and non-verbal dimensions (jesters, face-work, etc.)".

T. van Dijk also considers it possible to regard discourse as a genre, namely, scientific discourse, political discourse, etc. "Communicative events are usually tied to a specific social or institutional domain. In some cases, they may be constitutive of such a domain. Thus, the many types of legal discourse constitute the domain of "law", whereas types of political discourse largely constitute what we understand by "politics" or the "policy", and educational discourse the domain of education. That is, a domain is the typical contextual property that defines overall classes of genres, such as political discourse, medical discourse, scholarly discourse ${ }^{8}$.

The abovementioned approaches to the study of the concept of discourse are to some extent interrelated. Various methods and directions of discourse analysis explain the existence of a great number of definitions of this concept.

${ }^{7}$ Dijk T. A. van. Ideology: A Multidisciplinary Approach. London : Sage, 1998. P. 193-194.

${ }^{8}$ Dijk T. A. van. Ideology: A Multidisciplinary Approach. London : Sage, 1998. P. 214-215. 
In foreign and domestic studies, the understanding of discourse is not unambiguous. For example, the researcher V.V. Krasnykh has a point of view, according to which she interprets discourse as "verbalized thinking and speech activity, which includes linguistic and extralinguistic components," and the text as "an elementary unit of discourse," that is, in the researcher's approach, discourse is defined through text or text through discourse.

A researcher E.V. Temnova thinks that discourse can also be viewed as a process (verbalized speech-thinking activity) and as a result (fixed text), as well as in these two aspects simultaneously.

James Paul Gee and Michael Handford, in their definition of discourse, refer to "the meanings we give language and the actions we carry out when we use language in specific contexts". ${ }^{10}$

Within the framework of the communicative approach, discourse is perceived as verbal communication, dialogue, dialogical utterance, speech from the position of the speaker. The disadvantage of this approach is its high level of abstraction.

Another approach to the analysis of discourse is the structural-stylistic approach, when discourse is understood as "a non-textual organization of the spoken language, which is characterized by imprecise division into parts, the dominance of associative links, spontaneity, and high context". ${ }^{11}$

In our work, we adhere to the definition of discourse by N. D. Arutyunova, where "discourse is a coherent text in combination with extralinguistic - pragmatic, sociocultural, psychological, and other factors; text taken in the event aspect; speech, considered as a purposeful social action, as a component involved in the interaction of people and the mechanisms of the consciousness (cognitive processes)". Discourse is speech, "immersed in life". ${ }^{12}$ In this interpretation, the discourse is regarded as an expanded understanding of the text, as a text that is immersed in a specific communicative situation with information about the participants of communication and the conditions or circumstances of the situation.

The interpretation of the concept of discourse by a researcher A.I. Varshavskaya, who introduces the concept of discourse-text and

\footnotetext{
${ }^{9}$ Красных В.В. Виртуальная реальность или реальная виртуальность. Москва : Изд-во Диалог, МГУ, 1998. С. 190.

${ }^{10}$ Gee, J.P. and Handford, M. (eds). The Routledge Handbook of Discourse Analysis. Abingdon, Oxon : Routledge. 2012. P. 1.

${ }_{11}$ Карасик В.И. Структура институционального дискурса. Проблемы речевой коммуникации : межвуз. сб. науч. тр. Саратов : Изд-во Сарат. ун-та, 2000. С. 26.

12 Арутюнова Н.Д. Дискурс : Лингвистический энциклопедический словарь / под ред. В.Н. Ярцевой. Москва, Сов. энцикл., 1990. С. 136-137.
} 
considers discourse as a process of linguistic thinking, and the text as the result or product of this process, seems to be valid too.

Despite the great number of definitions of the concept of "discourse", it remains somewhat vague and ambiguous. Based on this, it can be classified as a universal concept in research, because the range of its interpretations is constantly expanding. And yet, with a high probability, further research of discourse, at least in the field of linguistics and methods of teaching languages, will be related to the concepts of "text" and "speech".

Foreign language professional discourse is defined in different ways by different researchers. Some researchers, for example Shaturnaya E. A. and Millrood R.P. define it as mastering of the necessary set of linguistic knowledge, as well as the ability to act adequately in certain conditions of professional communication.

Other researchers understand professional discourse as a speech professional act regarded as a specific concept of the social one, and professional activity is understood as social interaction with inherent speech, covering all aspects of professional life, including socio-cultural and foreign language aspect. Such point view has a researcher from Saint Petersburg N. A. Proschyants.

In the sphere of teaching foreign languages to students of humanities faculties, it is of particular interest to increase the effectiveness of the formation of foreign language communicative competence through teaching a foreign language professional discourse.

According to well-known linguistics researcher N.D. Galskova, "communicative competence is a person's ability to understand and generate utterances in foreign language in a variety of socially determined situations, taking into account the linguistic and social rules that native speakers adhere to" "13 Yet there are many other opinions on the matter.

Since linguists-researchers do not have a unified view on the composition of the components of communicative competence, we will take into consideration the opinion of the Council of Europe for Cultural Cooperation: Communicative language competence can be considered as comprising several components: linguistic, sociolinguistic, and pragmatic.

Linguistic competence includes lexical, phonological, syntactical knowledge and skills and other dimensions of language as a system. A given individual's communicative language competence relates not only to the range and quality of knowledge (e. g. in terms of phonetic distinctions made or extent and precision of vocabulary) but also to cognitive organization and

13 Гальскова Н.Д. Теория обучения иностранным языкам: лингводидактика и методология. Москва : Академия, 2005. С. 19. 
the way this knowledge is stored (various associative networks in which the speaker places a lexical item) and to its accessibility (activation, recall, and availability). Its organization and accessibility will vary from one individual to another or with the same individual (plurilingual person). Cognitive organization of vocabulary and storing of expressions, etc. depend on cultural features of the community, in which the individual has been socialized and where his/her learning has occurred.

Sociolinguistic competences refer to sociocultural conditions of language use. Through its sensitivity to social conventions (rules of politeness, norms governing relations between genders, classes or social groups, linguistic codification in functioning of a community), sociolinguistic component affects all language communication between representatives of different cultures.

Pragmatic competences are concerned with the functional use of linguistic resources (production of language functions, speech acts) drawing scripts of interactional exchanges. It also concerns the mastery of discourse, cohesion and coherence, the identification of text types and forms. It is not necessary to stress the impact of interactions and cultural environments in which such abilities are constructed. ${ }^{14}$

It follows from the aforesaid that the formation of foreign language communicative competence of students of humanities faculties should be aimed at reducing the intercultural distance between representatives of different societies by forming competencies that would help a future specialist to carry out professional communication in the context of interaction of different cultures, that is achievable when teaching a foreign language as professional discourse. The conditions for the implementation of the above is focus on the personal development of students based on the use of modern teaching methods that contribute to increasing motivation for learning a foreign language as a means of professional foreign language communication, i. e. the use of a foreign language professional discourse.

Teaching a foreign language discourse makes it possible to form communication skills, when students must understand what relations the communicants are in, in what situation communication takes place and how, depending on these factors, it is necessary to construct an utterance. It should be noted that the professional community is a community of people, which is characterized by a certain discourse, determined by the type of professional activity. "Foreign language professional discourse has all the categories inherent directly to discourse (proposition, explicature, implicature,

${ }^{14}$ Common European Framework of Reference for Languages: Learning, Teaching, Assessment. Council of Europe, Council for Cultural Co-operation. Education Committee. Cambridge University Press. 2001. 273 p. 
inference, reference, presupposition, mental lexicon). However, its formation is impossible without a formed foreign language communicative competence, which includes all types of competences that give new meaning to the categories of discourse and contribute to the implementation of an effective communication process" $"$.

Thus, the concept of a foreign language professional discourse arises, that is based on objective data and has as its goal the transfer of knowledge using strictly selected linguistic and stylistic means. It should be taken into consideration that a foreign language professional discourse is characterized by knowledge of certain number of linguistic and extralinguistic factors, among which a special subject network of communication for interlocutors, and a variety of types of texts and professional themes of communication can be distinguished. In this case, the so-called "mental lexicon (or vocabulary) acquires special significance as a category of discourse, since it is an active system in which new connections are constantly being established, which make it possible to find and realize the meanings of words determined by the professional sphere of communication"16.

We agree with S.K. Gural, who defines an important category of discourse - a mental lexicon, which means a vocabulary stored in a person's memory, which, unlike a traditional dictionary, is very flexible, multifaceted, mobile, stores many meanings and options of the words' use, on its basis word formation and the creation of new phrases and phrases are possible.

Nowadays all the lecturers know that while gaining higher education, a student gets acquainted with professional discourse. Professional discourse is a professional, legal, linguistic, and social field in which a specialist carries out his/her professional activity, exchanging information with other communicants. Analysis of professional language discourse requires special attention. From a linguistic point of view, professional discourse has its own special design, expressed, as a rule, in the vocabulary and style of speech.

"It is obvious that one of the most important competencies of any specialist who, in the process of his/her activity, deals with a professional foreign language, is discursive competence. For its formation, the systematic professionally oriented training of students is necessary, while students learn to perform communicative tasks presented in various forms" ${ }^{\text {"17 }}$. Thus, one of the main goals of language professionalization at the university is

\footnotetext{
${ }_{15}^{15}$ Макаров М.Л. Основы теории дискурса. Москва : ИТДГК Гнозис, 2003. С. 61.

16 Гураль С.К. Обучение иноязычному дискурсу как сверхсложной саморазвивающейся системе : автореф. дис... д-ра пед. наук. Тамбов, 2009. С. 23.

Поленова А.Ю., Постукян М.М. К проблеме ранней языковой профессионализации бакалавров в сфере экономики. Bопросы регулирования экономики. 2014. Том 5, № 1. С. 130.
} 
introduction of students to professional language discourse. Reflecting the model of future professional communication, the classroom language discourse is aimed at mastering the mechanisms of constructing utterances based on speech experience and understanding of the functioning of language means in the communication process. The content of professionally oriented language training can be considered as formation of the basis of professionally important competencies based on knowledge, abilities, skills, and preparation of students for professional communication in a foreign language. The content of language training can also be considered as the relationship of learning objects (language, speech, speech activity, culture), objects of acquisition (knowledge, skills, abilities, intercultural communication) and learning outcomes, or competencies (linguistic, communicative, and sociocultural).

Many linguists-researchers agree that components of the content of any language education include:

1. means of communication (phonetic, grammatical, lexical, stylistic, linguistic-cultural);

2. ability to choose the appropriate means in the process of communication;

3. skills formed in the process of training that enable students to use a foreign language;

4. knowledge of extralinguistic factors that influence communication;

5. spheres, themes, situations of communication, which help to acquire the content of education;

6. competences formed on the basis of knowledge, abilities and skills.

Further let us examine the lexical means of communication, in no way underestimating the significance of the others. We shall try to explain why, from our point of view, the lexical means are especially important in formation of the linguistic competence as one of the foundations of professional language discourse.

"Communication in the professional sphere is characterized by versatility, since various areas of scientific communication have a special thesaurus or vocabulary, interaction situations, communicative and practical intentions, and strategies for achieving them." ${ }^{18}$ To our mind, students can acquire the necessary information about a professional thesaurus or vocabulary through the study of speech/language activity (oral and written),

${ }^{18}$ Астафурова Т.Н. Стратегии коммуникативного поведения в профессиональнозначимых ситуациях межкультурного общения : автореф. дис. ... д-ра пед. наук. Москва : Московский государственный лингвистический университет, 1997. 47 с. 
that is, a discourse that reflects all the specific features of a foreign language linguistic society.

\section{Formation of the students' lexical communicator as the basis of professional discourse}

Motivation as one of the key factors that influence success in the process of learning foreign languages is recognized by both teachers and researchers "Without sufficient motivation even individuals with the most remarkable abilities cannot accomplish long-term goals, and neither are appropriate curricula and good teaching enough on their own to ensure student achievement". 19

The sources of motivation to study are both internal and external. It is obvious that any incentive circumstances of the external plan (for example, the need or the ability to communicate with native speakers) ultimately pass into the deep spheres of human activity, then acting as a strong internal motivational principle.

External sources of motivation include: 1) "interestingness" and enlightening, instructiveness of the lesson, and the educational process as a whole; 2) personal and professional qualities of the teacher; 3) success directly felt by the student in the process of mastering foreign languagespeech competence.

Meanwhile, the "feeling" of success, of progress in knowledge is most often observed only when a student experiences freedom when operating with linguistic signs of higher levels, which allows him/her to semantize (understand) utterances, super phrasal unities, text, where there is an involuntary jump from the plan of form into the realm of content. Here purposeful and "unorganized" efforts of students merge with the result, which is an essential psycho-motivation feedback.

It is no need to say, knowledge of vocabulary (lexicon) as a potential information field plays a decisive role. Hence, the creation of a lexical communicator, effective in terms of covering text arrays and reliable in terms of operation, a chain "linguistic form - meaning", as well as "meaning - linguistic form" of a lexical communicator is the primary task of a methodologist - organizer of learning. "To understand a text, learners need to know words, and knowing a word involves knowing: its spoken and written contexts of use, its patterns with words of related meaning" 20 .

19 Dornyei Z. Motivation in second and foreign language learning. Language Teaching.. 1998. Vol. 31 (3). P. 117.

${ }^{20}$ Carter R. Vocabulary: Applied Linguistic Perspectives. London : Routledge, 2012. p. 43. 
By the term "lexical communicator" we mean a specific sector of general speech competence, which is responsible for a set of knowledge, skills, and abilities in the normative use of words in semantic coding and in the perception of lexical units (items) in semantic decoding. The term "communicator" as a speech imitating (psycholinguistic) device was first used by E.P. Shubin in his well-known work "Language Communication and Teaching Foreign Languages". Somewhat later, studies appear in which the psychological mechanisms of possession of aspectual linguistic material are examined within the framework of a specific type of speech activity, that is essentially detailing of the concept of a communicator. ${ }^{21}$

Psycholinguistic aspects of the formation of a lexical communicator of students, from Petrushevskaya N.N. point of view include the following tasks: 1) mastering a productive vocabulary-minimum at the skill level; 2) mastering a receptive minimum at the skill level; 3) upbringing of socalled lexical "instinct or hunch", manifesting in the volume of a potential vocabulary (level of knowledge). ${ }^{22}$

The actual methodological aspects of the formation of a lexical communicator (LC) imply: 1) an adequate selection and acquisition of a minimum vocabulary for specific learning conditions (target setting, program, set of educational factors); 2) the development of a systemic lexically oriented block of exercises that develop LC in all basic types of speech activity within the framework of the existing or newly constructed educational system.

We have tried to consider some issues of compiling a minimum vocabulary for students of the non-linguistic faculty of the university, as well as the methodological and psycho-motivational role that it should play in the structure of the educational process in a foreign language.

All foreign language teachers know that students studying a foreign language have the greatest difficulties in mastering its lexical system. Unlike the phonetic and grammar systems, which are practically closed, the vocabulary of the language is an open, limitless sphere in the bosom of any natural (living) language. In a modern developed language, there are approximately 100 thousand lexical items (LIs), which appearance in the text seems unpredictable, random (which, in fact, it is), and, according to the

21 Куклина С.С. Ситуативно-функциональная обусловленность механизмов лексического навыка говорения. Коммуникативный метод обучения иноязычной речевой деятельности. Воронеж, 1992. С. 36-47.

22 Петрушевская Н. Н. Формирование и расширение лексического запаса для чтения специальных текстов. Иностранные языки в высшей школе. Москва : Высш. шк., 1987. Вып. 19. С. 121-126. 
observations of speech statisticians, the most informative parts of the text are provided primarily by low-frequency words, or "rare" ones.

The constant encounter of the student with unfamiliar LIs irritates $\mathrm{him} / \mathrm{her}$, reduces the motivational potential. Moreover, the further advancement in studying the program does not seem to remove this problem. On the contrary, it is exacerbated, gaining a new impetus when degree seekers move on to work with the original scientific literature. We find confirmation of this in the studies of foreign linguists D. Gardner and M. Davis. "Almost without exception, experts are calling for more explicit instruction of academic vocabulary, including more focused lists of "core" academic vocabulary, as well as lists specific to certain disciplines of education (e. g. history, philosophy, law and political science). Such lists are useful in establishing vocabulary learning goals, assessing vocabulary knowledge and growth, etc." 23

Taking into consideration the above, the importance of a reliable, effective vocabulary minimum cannot be overestimated. While compiling it, one should proceed from the fact that no matter how colossal the vocabulary of the studied language is, it is always possible to single out the core, that constitutes an important and necessary part of the lexical communicator of each native speaker, without which the implementation of linguistic communication is impossible.

We are talking about a minimum dictionary containing only the vocabulary that should be learned first when studying any foreign language in certain conditions.

It is known that the vocabulary minimum can be created both for teaching a language "in general" and for communicating with individual groups of the linguistic community (social, professional, regional, age, etc.). Such dictionaries differ significantly in their size and composition, since they can include terminology, social vocabulary, argot, etc. The size in this case can vary from several hundred (for example, Basic English) to many thousands of lexical items. However, the obligatory presence in each of them of the core part of the vocabulary ensures the possibility of free communication between members of the language community.

Creation of vocabulary-minimums is a relatively young branch of lexicography, but one can speak of it as a separate discipline - educational lexicography, under which V.V. Morkovkin, for example, understands "a complex linguo-methodological discipline, the content of which is

${ }^{23}$ Gardner D., Davies M. A New Academic Vocabulary List. Applied Linguistics. 2014. 35 (3). P. 305-327. 
theoretical and practical aspects of describing vocabulary for educational purposes" 24 .

This definition should be substantially supplemented by the reference that the basis of educational lexicography is scientifically grounded selection, and its quality decides the whole matter.

The practice of compiling lexical minimums indicates shortcomings in this very aspect: the extremely limited LIs minimum often includes "optional" vocabulary, while the immensely necessary vocabulary often remains outside.

The reasons for the inadequacy of many vocabulary-minimums are as follows: the basis of their creation is mainly based on "linguo-centric" principles, that is, provisions focused on the internal rules and mechanisms of language but neglecting or ignoring its communicative characteristics and properties, its main purpose - to serve as a means of communication.

Developing the issues of modeling the minimum vocabulary, the methodologist must be aware of: 1) educational conditions that determine the quantitative parameters of the minimum vocabulary; 2) the social and communicative position of a graduate of a higher educational institution a future specialist, whose linguistic competence is supposed to be formed; 3 ) the role that in his/her general speech competence will be occupied by the main types of speech communicative activity (in what volume, on what material).

Let us briefly consider the above prerequisites for the formation of the lexical minimum.

The first question is: what should be the size of the minimum vocabulary? Methodologists believe that knowledge of 1000-1600 most common words may be required to steer a conversation on everyday topics. A detailed review of this problem is contained in the work of B.A. Lapidus. ${ }^{25}$ The problem of the number of LIs, the knowledge of which is needed to understand the written text, is solved somewhat differently. In the language of monographs, newspapers, popular science, and literary and artistic works, we find a great number of words that are rarely used or do not occur at all in everyday life.

The "critical" size of the commonly used vocabulary (1000 LIs) established for oral speech is not able to ensure understanding of a written text, particularly the special one.

24 Морковкин В.В. Типология филологических словарей. Vocabulum et vocabularium. Вестник Харьковского политехнического университета. Харьков, 1994. Вып. 1, № 19. С. 13-23.

25 Лапидус Б.А. Проблемы содержания обучения языку в языковом вузе. Москва : Высш. шк., 1986. 144 с. 
The search-informative understanding of a source happens when at least $70 \%$ of the words are familiar to a reader or speaker. However, such a ratio does not seem optimal, since it only gives a general, approximate understanding of a work, which is unacceptable for a special (for example, legal) oral or written text. Welding dictionary data, for example, show that 3612 word-forms cover $90 \%$ of the text. ${ }^{26}$

The size of students' vocabulary is influenced by the learning conditions - the duration of the course, the number of classroom hours per week, the teaching method, the quality, and nature of the exercises. Therefore, in the learning process, adjustments are possible.

Since learning to read is aimed at achieving adequate understanding, there should be at least $85 \%$ of familiar words in the text, which will correspond to a passive vocabulary of about 2800 most common words. Lexical items of the active minimum vocabulary (1600 LIs) constitute its stable core. The composition of the remaining 1200 receptively acquired words, built on top of the active core (although they belong to the most essential for understanding the text), can undergo certain changes caused by shifts in the formulations of learning goals, changes in the number of class hours, and changes in organizational forms of teaching/learning.

It should also be remembered that to this educational minimum, the student will add 500 LIs, representing highly specialized terminology (for example, the sublanguage of jurisprudence: to accuse, advocacy, to allege, attorney, barrister, bill, burglary, convict, coroner, crime, courtroom, dock, evidence, forgery, guilty, investigate, jail, jury, law, legal, murder, offence, plaintiff, probation, prosecutor, to rob, shoplifting, solicitor, trial, will, witness, etc.).

Let us move on to considering approaches, principles, and procedures for selecting the minimum vocabulary. The history of methodology has registered different approaches to the selection and acquisition of lexical minimum. Among them are deductive-lexicographic, intuitive-pragmatic, thematicconceptual, inductive, statistical, mixed (combined) and other approaches.

The most fruitful and effective, both from a methodological and psychomotivational point of view, is the communicative (more precisely, the communicative-inductive approach. It was studied and substantiated in the works of V.L. Skalkin. ${ }^{27}$ This approach is based on an accurate definition of

${ }^{26}$ Петрушевская Н.Н. Формирование и расширение лексического запаса для чтения специальных текстов. Иностранные языки в высшей школе. Москва : Высш. шк., 1987. Вып. 19. С. 121-126.

27 Скалкин В.Л. Коммуникативные основы отбора языкового материала для обучения устной иноязычной речи. Коммуникативный метод обучения иноязычной речевой деятельности. Воронеж, 1983. С. 21-27. 
the social-communicative position of a higher educational institution graduate, in our case - a certified specialist (in our case, a lawyer).

The socio-psycholinguistic approach to the functioning of a language as an object of learning (in particular, its lexical system) makes it possible to assess accurately the text-forming role of certain layers of the LIs minimum and the communicative decorum that reveals their semantic value and determines their real role in speech activity. For LIs exist not only in the "text", but also in a concentric system of communicative categories, such as the sphere and type of communication, a typical speech situation, etc.

Thus, the "sowing", or selecting of the lexical inventory from the text should be preceded by targeted selective work at the communicative level the selection of written materials (for the receptive part of the minimum) and the selection of typical communication situations (for the reproductive minimum). In both cases, the professional and personal interests of students should be taken into consideration, that should provide a motivational component of the vocabulary learning at this stage.

Each stage and "site" of selection uses its own selection rules. So, if the statistical principle is suitable for processing written sources for the passive stock of LIs, then while completing a productive vocabulary, the leading one should be the principle of situational-thematic modeling, supplemented by the criteria of semantic importance, availability of concepts, the relationship of LIs to a certain lexical microsystem, etc. This is where complex selection principles can be applied.

Thus, the communicative approach involves the use of differentiated rules and selection procedures that are most consistent with the nature and purpose of these functional-methodological vocabulary classes, which form the minimum for specific teaching/learning conditions. ${ }^{28}$ The use of test materials of the educational minimum, compiled on the bases of the described procedures in classroom lessons, aroused great interest among students.

Giving a general description of the lexically oriented block of forms of work that develop the LC, we note that both in the training-preparatory and in the communicative-speech phase they are distinguished by some qualities.

1. They provide a systematic, methodologically relevant for typological difficulties and information needs replenishment of the vocabulary that students have already acquired;

28 Яременко Г.И. К вопросу о репродуктивном лексическом минимуме для первого этапа обучения иностранному языку в техническом вузе (на материале английского языка). Анализ содержания курса иностранного языка. Томск, 1989. Вып. V. C. 112-119. 
2. Any LIs introduced at one stage or another of the educational process are worked out on communicative, contextually interesting (at an advanced stage - professional) material;

3. The methodical apparatus of the block provides for repeatability of LIs with a frequency adequate to the typology of their difficulty (learnability);

4. The whole complex of activity forms ensures the formation of a so called reserve vocabulary (vocabulaire disponible). ${ }^{29}$

The proposed system allows at all stages of work on the development of students' LC to keep in mind the psycho-motivational aspects of teaching vocabulary. Revealing the meaning of words, the teacher connects the student's lexical communicator through the meanings and semantic fields of separate layers of vocabulary to extralinguistic content that has cognitive and motivational characteristics. This happens according to the following general correlation scheme:

REALIA life of the country of the target language;

TERMS new data, concepts of professional domain and legal science;

SOCIAL AND POLITICAL VOCABULARY socio-economic, political situation in countries, regions, in the world;

ANTHROPONYMS ------------ the life and work of prominent historical figures, politicians, legal theoreticians and lawyers of a particular country;

PRAGMONYMS activities of foreign legal corporations, trade, production, and research organizations.

\section{CONCLUSIONS}

Summing up the above, we can make a conclusion about the dialectical interconnectedness of the methodological and psycho-motivational aspects of the vocabulary/lexis teaching system - the formation of a lexical communicator. The more correct is the linguistic base of the lexical communicator and the ways of its development in a purely methodological aspect, the stronger and more stable is students' professional potential.

Still, it should be admitted that we face some problems while moving from language as system towards language as discourse. Though the vocabulary of the English language is composed of a colossal repository of lexical units and phrases, there are important domains where we should move away from considering the lexicon as a part of the language system towards viewing it as a resource for the discourse formation. All lecturers

${ }^{29}$ Гугенейм Г. Некоторые выводы статистики словаря. Методика преподавания иностранных языков за рубежом. Москва : Прогресс, 1976. С. 299-305. 
know that both grammar and lexis, which form a big portion of every language are often taught from the viewpoint of language as system. However, introducing the concepts of lexis as discourse encourages understanding of language form and function, that stimulate more effective communication.

The syllabus can potentially bridge the gap between language as system and language as discourse include, from the point of view of Brian Clancy and Michael McCarthy: discourse roles; types of verbal exchange that are natural in different contexts; natural turn-taking; discourse marking; creating and maintaining relationships; goal-orientation. But not all these points offer ready-made linguistic repository that can be written into the syllabus. Everything requires thinking, planning and reassessment of methods, materials, activities, and classroom practices. ${ }^{30}$

Question how to distribute discourse roles in the classroom affect not only the content of the syllabus, but also methods of teaching and classroom activities. An important issue is how to create a syllabus which encourages the transition from language system to discourse in areas of language where the available linguistic repository is not so well-described as, for example, the tense system, the prepositions, the names of the days of the week, verbs of the senses, etc. Quite often, attempts to explain what discoursal competence means in foreign language contexts is not defined in exact terms. Defining and specifying content are the subsequent problems for anyone willing to incorporate the sphere of discourse into a planned syllabus. Another problem lies in the fact that there is a wide variety of contexts in which language use changes according to the situation and the participants. ${ }^{31}$

Nevertheless, we see the prospect of further research in creation of a vocabulary minimum for creation of lexical communicator with the aim of using it in classroom and self-study to achieve a higher level of foreign language proficiency.

\section{SUMMARY}

The article deals with professional discourse or communication in professional sphere that is characterized by versatility, since various areas of such communication have a special thesaurus or vocabulary, interaction situations, communicative and practical intentions, and strategies for

${ }^{30}$ McCarthy M. and Clancy B. From Language as System to Language as Discourse. In Routledge handbook of English language Teacher Education. Routledge. 2019. P. 201-215.

${ }^{31}$ Clancy B. Investigating Intimate Discourse: Exploring the Spoken interaction of Families, Couples and Friends. London : Routledge, 2015. 194 p. 
achieving them. Hence, the creation of a lexical communicator, effective in terms of covering oral and written text arrays and reliable in terms of operation, a chain "linguistic form - meaning", as well as "meaning linguistic form" of a lexical communicator is the primary task of a methodologist - organizer of learning.

While doing a research we found out that actual methodological aspects of the formation of a lexical communicator imply: 1) an adequate selection and acquisition of a minimum vocabulary for specific learning conditions (target setting, program, set of educational factors); 2) the development of a systemic lexically oriented block of exercises that develop lexical communicator in all basic types of speech activity within the framework of the existing or newly constructed educational system.

We are of opinion that students while learning a foreign language have the greatest difficulties in mastering its lexical system because unlike the phonetic and grammar systems, which are practically closed, the vocabulary of a language is an open, limitless sphere of any natural language. Taking it into consideration, the importance of a reliable, effective vocabulary minimum cannot be overestimated.

Unfortunately practice of compiling lexical minimums indicates shortcomings in this very aspect: the extremely limited lexical minimum often includes "optional" vocabulary, while the most necessary vocabulary often remains outside.

In our work we made a comparative study of different approaches to the selection and acquisition of lexical minimum (among them deductivelexicographic, intuitive-pragmatic, thematic-conceptual, inductive, statistical, mixed, or combined and others); the most effective, both from a methodological and psycho-motivational point of view, is the communicative approach because it is based on an accurate definition of the social-communicative position of a higher educational institution graduate.

We have proved that selecting of the lexical inventory from the oral and written texts should be preceded by targeted selective work at the communicative level - the selection of written materials (for the receptive part of the minimum) and the selection of typical communication situations (for the reproductive minimum) because lexical items exist not only in texts, but also in a concentric system of communicative categories, such as the sphere and type of communication, a typical communication situation, etc.

As a result of our research, it is possible to deduce that each stage of selection needs its own selection rules. If the statistical principle is suitable for processing written sources for the passive stock of lexical items, then while completing a productive vocabulary, the leading one should be the principle of situational-thematic modeling, supplemented by the criteria of semantic importance, availability of concepts, the relationship of lexical items to a certain lexical microsystem, that is to apply complex selection principles. Consequently, the communicative approach involves the use of 
differentiated rules and selection procedures that are most consistent with the nature and purpose of these functional-methodological vocabulary classes, which form the minimum for specific teaching/learning conditions.

At all stages of work on the development of students' lexical communicator a lecturer must bear in mind the psycho-motivational aspects of teaching vocabulary: revealing the meaning of words, the teacher connects the student's lexical communicator through the meanings and semantic fields of separate layers of vocabulary to extralinguistic content that has cognitive and motivational characteristics.

At the end of our research, we reached a conclusion about the dialectical interconnectedness of the methodological and psycho-motivational aspects of the vocabulary teaching system - the formation of a lexical communicator: the more correct is the linguistic base of the lexical communicator and the ways of its development in a purely methodological aspect, the stronger and more stable is students' professional discourse potential.

\section{REFERENCES}

1. Арутюнова Н.Д. Дискурс : Лингвистический энциклопедический словарь / под ред. В.Н. Ярцевой. Москва, Сов. энцикл., 1990. 688 с.

2. Астафурова Т.Н. Стратегии коммуникативного поведения в профессионально-значимых ситуациях межкультурного общения : автореф. дис. ... д-ра пед. наук. Москва : Московский государственный лингвистический университет, 1997. 47 с.

3. Варшавская А.И. Смысловые отношения в структуре языка: (на материале современного английского языка). Ленинград : Изд-во Ленингр. ун-та, 1984. 134 с.

4. Гальскова Н.Д. Теория обучения иностранным языкам: лингводидактика и методология. Москва : Академия, 2005. 336 с.

5. Гугенейм Г. Некоторые выводы статистики словаря. Методика преподавания иностранных языков за рубежом. Москва : Прогресс, 1976. C. 299-305.

6. Гураль С.К. Обучение иноязычному дискурсу как сверхсложной саморазвивающейся системе : автореф. дис... д-ра пед. наук. Тамбов, 2009. $47 \mathrm{c}$.

7. Гураль С.К. Язык как саморазвивающаяся система. Томск : Изд-во Том. ун-та, 2012. $118 \mathrm{c.}$

8. Дейк Т.А. ван, Кинч В. Стратегии понимания связного текста. Новое в зарубежной лингвистике. Когнитивные аспекты языка. Москва, 1988. № 23. С. 153-211.

9. Звегинцев В.А. Тезисы Пражского Лингвистического Кружка. История языкознания XIX-XX веков в очерках и извлечениях. Москва : Просвещение, 1965. Ч. II. С. 123-140. 
10. Карасик В.И. Структура институционального дискурса. Проблемы речевой коммуникаиии : межвуз. сб. науч. тр. Саратов : Изд-во Сарат. ун-та, 2000. С. 25-33.

11. Красных В.В. Виртуальная реальность или реальная виртуальность. Москва : Изд-во Диалог, МГУ, 1998. 352 с.

12. Куклина С.С. Ситуативно-функциональная обусловленность механизмов лексического навыка говорения. Коммуникативный метод обучения иноязычной речевой деятельности. Воронеж, 1992. С. 36-47.

13. Лапидус Б.А. Проблемы содержания обучения языку в языковом вузе. Москва : Высш. шк., 1986. 144 с.

14. Макаров М.Л. Основы теории дискурса. Москва : ИТДГК Гнозис, 2003. 280 с.

15. Морковкин В. В. Типология филологических словарей. Vocabulum et vocabularium. Вестник Харьковского политехнического университета. Харьков, 1994. Вып. 1, № 19. С. 13-23.

16. Петрушевская Н.Н. Формирование и расширение лексического запаса для чтения специальных текстов . Иностранные языки в высшей школе. Москва : Высш. шк., 1987. Вып. 19. С. 121-126.

17. Поленова А.Ю., Постукян М.М. К проблеме ранней языковой профессионализации бакалавров в сфере экономики. Bonpocbl регулирования экономики. 2014. Том 5, № 1. С. 128-133.

18. Прощьянц Н.A. Формирование иноязычных лингвистических компетенций в профессиональном дискурсе. Язык и культура. СанктПетербург. 2010. № 6. С. 34-38.

19. Рахман С.Е. Статус лексических навыков чтения. Коммуникативный метод обучения иноязычной речевой деятельности. Воронеж, 1992. С. 58-65.

20. Скалкин В.Л. Коммуникативные основы отбора языкового материала для обучения устной иноязычной речи. Коммуникативный метод обучения иноязычной речевой деятельности. Воронеж, 1983. C. 21-27.

21. Темнова Е.В. Современные подходы к изучению дискурса. Язык, сознание, коммуникачия. Сборник научных статей. Москва, 2004. Вып. 26. С. 31-37.

22. Шатурная Е.А. Методика обучения устному иноязычному профессиональному дискурсу средствами учебно-речевых ситуаций и ролевых игр : автореф. дис. ... канд. пед. наук. Тамбов, 2009. 26 с.

23. Шубин Э.П. Языковая коммуникация и обучение иностранным языкам. Москва : Просвещение, 1982. $351 \mathrm{c}$.

24. Яременко Г. И. К вопросу о репродуктивном лексическом минимуме для первого этапа обучения иностранному языку в техническом вузе (на материале английского языка). Анализ содержания курса иностранного языка. Томск, 1989. Вып. V. С. 112-119. 
25. Brown G., Yule G. Discourse Analysis. Cambridge: Cambridge Univ. Press, 1983. $288 \mathrm{p}$.

26. Carter R. Vocabulary: Applied Linguistic Perspectives. London : Routledge, 2012. 320 p.

27. Clancy B. Investigating Intimate Discourse: Exploring the Spoken interaction of Families, Couples and Friends. London : Routledge, 2015. 194 p.

28. Common European Framework of Reference for Languages: Learning, Teaching, Assessment. Council of Europe, Council for Cultural Co-operation. Education Committee. Cambridge University Press. 2001. 273 p.

29. Davies M., Gardner D. A Frequency Dictionary of Contemporary American English. Word Sketches, Collocates and Thematic Lists. London : Routledge, 2010. 368 p.

30. Dijk T. A. van. Ideology: A Multidisciplinary Approach. London : Sage, 1998.365 p.

31. Dornyei Z. Motivation in second and foreign language learning. Language Teaching.. 1998. Vol. 31 (3). P. 117-135.

32. Gardner D., Davies M. A New Academic Vocabulary List. Applied Linguistics. 2014. 35 (3). P. 305-327.

33. Gee, J.P. and Handford, M. (eds). The Routledge Handbook of Discourse Analysis, Abingdon, Oxon: Routledge. 2012. 682 p.

34. Matei M. Discourse markers as Functional Elements. Bulletin of the Transilvania University of Brasov : Philology and Cultural Studies. 2010. Vol. 3 (52). P. 119-126.

35. McCarthy, M. and Clancy, B. From Language as System to Language as Discourse. In Routledge handbook of English language Teacher Education. Routledge. 2019. P. 201-215.

36. Millrood R.P. Discourse for Teaching Purposes. Методология исследования: дискурс в обучении иностранному языку : междунар. сб. науч. тр. Тамбов : Изд-во Тамбов. ун-та, 2002. С. 23-30.

37. Schiffrin D. Discourse Markers. Cambridge, Cambridge University Press, 1987. $364 \mathrm{p}$.

38. Schiffrin D. Approaches to Discourse. Oxford - Cambridge, Mass. : Basil Blackwell, 1994. 195 p.

\section{Information about the author: Varieshkina N. V.,}

Candidate of Pedagogical Sciences, Associate Professor at the Department of Foreign Languages № 1 National University "Odesa Law Academy" 23, Fontanska doroha, str., Odesa, 65009, Ukraine 